\title{
PRIORITIZING ISSUES OF MALAYSIAN VISION 2020: AN APPLICATION OF THE ANALYTIC HIERARCHY PROCESS
}

\author{
Rafikul Islam \\ Department of Business Administration \\ Kulliyyah of Economics and Management Sciences \\ International Islamic University Malaysia \\ P.O. Box 10, 50728 Kuala Lumpur \\ E-mail: rislam@iium.edu.my
}

\begin{abstract}
By the year 2020, Malaysia aspires to become a fully developed nation. This lofty vision, known as Vision 2020, was unveiled by the former Prime Minister of Malaysia Tun Dr. Mahathir bin Mohamad in February 28, 1991. By the present time, it is generally felt that the nation has achieved 50 to 60 per cent of the objectives of Vision 2020. "Many more things need to be done by many more people". What need to be done and in what areas? This is the question we asked to 759 people living in Malaysia (Malaysians as well as Internationals) in a nationwide survey. As expected, the respondents touched upon a wide variety of issues pertaining to education, economy, technology, quality of life, law and order, R\&D, and so on. Upon compilation of all the articulated issues, we developed an affinity diagram. The Analytic Hierarchy Process has been applied in each component of the affinity diagram. This exercise identifies the main issues for implementation. The present research findings are expected to provide useful guidelines to the policy makers at the national level in course of fine tuning the Vision 2020 strategies $^{1}$.
\end{abstract}

Keywords: vision 2020, affinity diagram, analytic hierarchy process, Malaysia

\section{Introduction}

Vision is a long-term objective that provides an insight into the direction, which a nation/organization needs to move, just as an identified destination gives a direction to a journey. A well-defined vision gives focus and direction to the formulation of current programmes and in turn links current actions to the achievement of future goals. Malaysian Vision 2020 was unveiled by the former Prime Minister of Malaysia, Tun Dr. Mahathir bin Mohamad at the inaugural meeting of the Malaysian Business Council on the $28^{\text {th }}$ of February, 1991. The gist of this vision is to develop Malaysia as a fully developed country ${ }^{\mathrm{i}}$. The Vision 2020 statement is (Rahman, 1993, p. 271):

"By the year 2020, Malaysia is to be a united nation, with a confident Malaysian society, infused by strong moral and ethical values, living in a society that is democratic, liberal, caring, economically just

${ }^{1}$ Acknowledgement: The author is thankful to his colleague Yusof Ismail for his contribution to the questionnaire development and data collection. 


\section{Proceedings of the International Symposium on the Analytic Hierarchy Process 2009}

and equitable, progressive and prosperous, and in full possession of an economy that is competitive, dynamic, robust and resilient."

In the first ever open National Seminar on Vision 2020 (henceforth referred to as V-2020, for brevity) in 1991, the then Deputy Prime Minister of Malaysia, Tun Abdul Ghafar Baba, stressed Malaysia should not only be developed economically, but also in all dimensions including politics, social, spiritual, psychological as well as cultural. More importantly, in the efforts towards a developed status, Malaysia should also endeavor to create a united, confident, socially just and politically stable Malaysian society, in which everybody has a place, and takes pride in being a Malaysian ${ }^{\text {ii }}$. In short, V-2020 reflects the vision of a fully developed and industrialized Malaysia by the year 2020, in all dimensions. Tun Mahathir Mohamad stated this as follows (Mohamad, 1991, p. 1):

Malaysia should not be developed only in the economic sense. It must be a nation that is fully developed along all the dimensions: economically, politically, socially, spiritually, psychologically and culturally. We must be fully developed in terms of national unity and social cohesion, in terms of our economy, in terms of social justice, political stability, system of government, quality of life, social and spiritual values, national pride and confidence.

Specific objectives of V-2020 are as follows:

- To have sufficient food and shelter with easy access to health and basic essentials

- To eradicate poverty

- To remove the identification of race with major economic functions and to have a fair distribution with regard to the control, management and ownership of the modern economy

- To maintain annual population growth rate of $2.5 \%$

- To double real GDP every ten years between 1990 and 2020 AD

- To have a balanced growth in all sectors namely: industry, agroforestry, energy, transport, tourism and communications, banking, that is technologically proficient, fully able to adapt, innovative, with a view to always moving to higher levels of technology

From the above, it is clear that the focus of V-2020 is not only on the economic aspects of development but also on the interrelated aspects such as social justice, quality of life, moral and ethical values, work ethics and so on (Kassim, 1993). According to Tun Mahathir, by the year 2020, Malaysia can be a united nation, with a confident Malaysian society, infused by strong moral and ethical values, living in a society that is democratic, liberal and tolerant, caring, economically just and equitable, progressive and prosperous, and in full possession of an economy that is competitive, dynamic, robust and resilient.

To achieve the various objectives of V-2020, the former PM identified nine challenges and according to him, if these challenges are successfully addressed, then Malaysia will be able to realize V-2020. These challenges are supported and promulgated by other Malaysians including various ministers, by and large. Here are those nine challenges:

1. Establishing a united Malaysian nation

2. Creating a psychologically liberated, secure, and developed Malaysian society

3. Developing a mature democratic community

4. Forming a community that has high morale, ethics, and religious strength

5. Establishing a mature, liberal and tolerant society

6. Establishing a scientific and progressive society

7. Establishing a fully caring society

8. Ensuring an economically just society 
9. Establishing a prosperous society.

Mohamad (1991, p. 1) said:

There can be no fully developed Malaysia until we have finally overcome the nine central strategic challenges that have confronted us from the moment of our birth as an independent nation.

V-2020 is a buzz word in Malaysia and the government is keen to achieve this lofty vision. However, when we talk to the public about this, they are, in general, on the opinion that many more things need to be done before the nation achieves the vision. A formal questionnaire was developed to know the present level of achievement. The details are provided in the following sections.

\section{Public opinion on realization of $\mathbf{V - 2 0 2 0}$}

We have been able to contact 759 people in Malaysia for the purpose of filling out the questionnaire. All the people were contacted personally. Since the survey is on the national vision, the respondents contacted belonged to all the states of Malaysia. In fact, we and our nominated research assistants visited all the 13 states of Malaysia to collect the feedback. The details of the demographic information are provided in Table 1.

Table 1. Respondents' demographic information

\begin{tabular}{|c|c|c|}
\hline Variable* & Frequency & Percent \\
\hline $\begin{aligned} \text { Gender } & \\
\bullet & \text { Male } \\
\bullet & \text { Female }\end{aligned}$ & $\begin{array}{l}417 \\
342\end{array}$ & $\begin{array}{l}54.9 \\
45.1\end{array}$ \\
\hline $\begin{aligned} & \text { Race } \\
& \text { - } \text { Malay } \\
& \text { - } \text { Chinese } \\
& \text { - } \text { Indian } \\
&\end{aligned}$ & $\begin{array}{l}510 \\
82 \\
61 \\
106\end{array}$ & $\begin{array}{l}67.2 \\
10.8 \\
8.0 \\
14.0 \\
\end{array}$ \\
\hline $\begin{array}{cl}\text { Age group } \\
\text { - } & 20 \text { years or below } \\
\text { - } & 21-30 \text { years } \\
\text { - } & 31-40 \text { years } \\
\text { - } & \text { Above } 50 \text { years }\end{array}$ & $\begin{array}{l}23 \\
375 \\
204 \\
99 \\
57\end{array}$ & $\begin{array}{l}3.0 \\
49.4 \\
26.9 \\
13.0 \\
7.5\end{array}$ \\
\hline $\begin{array}{cl}\text { Highest level of education } \\
\text { - O Level } \\
\text { - } & \text { A Level } \\
\text { - } & \text { Diploma } \\
\text { - } & \text { Professional } \\
\text { - } & \text { Masters } \\
\text { - } & \text { Ph.D. } \\
\text { - Others }\end{array}$ & $\begin{array}{l}28 \\
17 \\
100 \\
38 \\
353 \\
120 \\
59 \\
41\end{array}$ & $\begin{array}{l}3.7 \\
2.2 \\
13.2 \\
5.0 \\
46.5 \\
15.8 \\
7.8 \\
5.4\end{array}$ \\
\hline \begin{tabular}{cl}
\multicolumn{2}{l}{ Marital status } \\
$\bullet$ & Single \\
$\bullet$ & Married \\
$\bullet$ & Divorced
\end{tabular} & $\begin{array}{l}357 \\
395 \\
4\end{array}$ & $\begin{array}{l}47.0 \\
52.0 \\
0.5\end{array}$ \\
\hline $\begin{array}{cl}\text { Type of employment } \\
\text { - } & \text { Public } \\
\text { - } & \text { Private } \\
\text { - } & \text { Self-employed } \\
\text { - } & \text { Others }\end{array}$ & $\begin{array}{l}269 \\
289 \\
61 \\
133\end{array}$ & $\begin{array}{l}35.4 \\
38.1 \\
8.0 \\
17.5\end{array}$ \\
\hline
\end{tabular}

* Missing entries are not considered in the table. 
Malaysia is a multiracial country. In additional to this, the country's total population consists of a sizable percentage of foreigners, who belong to mainly three categories: students, professionals, and workers. We were also interested to know their views on the nation's aspiration to become developed and how far the country has progressed. However, we considered only the professionals from among the foreigners for obtaining the feedback. The statistics of the respondents across various states of Malaysia and the world are provided in Table 2. It is to be noted that out of 759 respondents, 106 are foreigners belonging to 28 countries (the list of countries are arranged alphabetically starting and ending with Afghanistan and Zimbabwe, respectively $)^{2}$.

Table 2. The statistics of the respondents across various states of Malaysia and the world

\begin{tabular}{|l|c|l|c|l|c|}
\hline \multicolumn{2}{|c|}{ Malaysian } & \multicolumn{4}{c|}{ International } \\
\hline State & $\begin{array}{c}\text { No. of } \\
\text { respondents }\end{array}$ & Country & $\begin{array}{c}\text { No. of } \\
\text { respondents }\end{array}$ & Country & $\begin{array}{c}\text { No. of } \\
\text { respondents }\end{array}$ \\
\hline Johor & 44 & Afghanistan & 1 & Oman & 1 \\
\hline Kedah & 51 & Albania & 1 & Pakistan & 6 \\
\hline Kelantan & 71 & Algeria & 3 & Saudi Arabia & 6 \\
\hline Kuala Lumpur & 69 & Bangladesh & 15 & Senegal & 1 \\
\hline Malaka & 39 & China & 2 & Singapore & 1 \\
\hline Pahang & 18 & Egypt & 2 & Somalia & 1 \\
\hline Penang & 15 & Ghana & 1 & Sri Lanka & 1 \\
\hline Perak & 70 & India & 6 & Sudan & 1 \\
\hline Perlis & 2 & Indonesia & 14 & Tanzania & 1 \\
\hline Sabah & 8 & Iran & 2 & Tunisia & 1 \\
\hline Sarawak & 41 & Kenya & 1 & Turkey & 1 \\
\hline Selangor & 159 & Malawi & 1 & Uganda & 2 \\
\hline Negeri Simbilan & 41 & Maldives & 2 & Yemen & 1 \\
\hline Terenganu & 20 & Nigeria & 2 & Zimbabwe & 1 \\
\hline
\end{tabular}

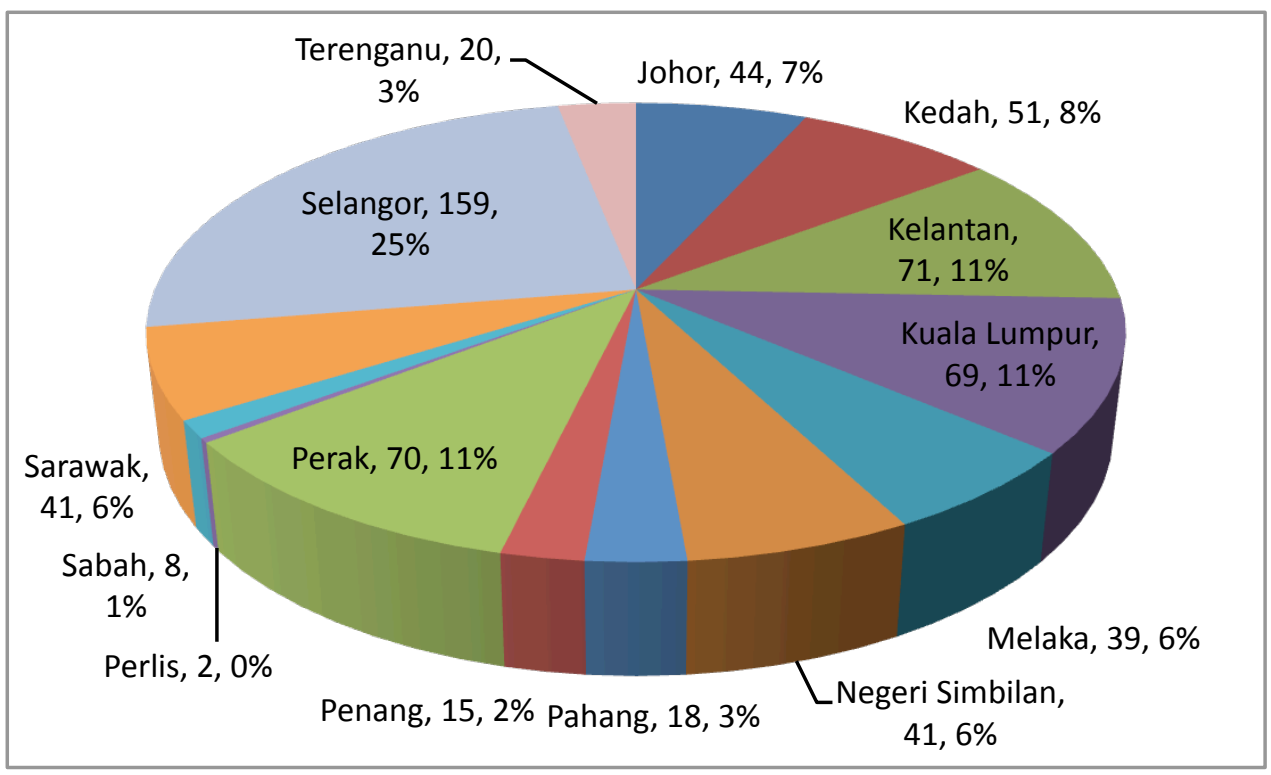

\footnotetext{
${ }^{2}$ Not all the respondents mentioned their state or nationality in the questionnaire.
} 
Figure 1. Responses received from the various states of Malaysia.

The number and percentages of the respondents who provided feedback from various states in Malaysia are also shown by means of a pie chart (see Figure 1). As it is shown, the highest number of respondents are from the state of Selangor (the most developed state in Malaysia (Staff Reporter, 2005) followed by Kelantan, Perak and Kuala Lumpur (a federal territory).

After obtaining the demographic information, the respondents were asked seven Yes/No type of questions. The frequency distribution of the responses is provided in Table 3. A number of observations can be made from these responses. More than $50 \%$ of the respondents either said 'No' or 'Not sure' whether Malaysia can achieve the status of developed nation by 2020 . However, proportional hypothesis test does not confirm that the minority said 'Yes' $(p=0.1583)$. Therefore, the responses on the question is evenly distributed between 'Yes' and 'No \&Not sure'.

Table 3. Analysis of people's responses against Yes/No type of questions

\begin{tabular}{|l|l|l|l|}
\hline Question & Yes & No & Not Sure \\
\hline $\begin{array}{l}\text { Do you think that Malaysia can achieve the status of developed nation by } \\
2020 ?\end{array}$ & $\begin{array}{l}366 \\
(48.2)\end{array}$ & $\begin{array}{l}118 \\
(15.5)\end{array}$ & $\begin{array}{l}262 \\
(34.5)\end{array}$ \\
\hline $\begin{array}{l}\text { Do you think that the initiatives from the government to achieve the status } \\
\text { of developed nation are enough? }\end{array}$ & $\begin{array}{l}190 \\
(25.0)\end{array}$ & $\begin{array}{l}315 \\
(41.5)\end{array}$ & $\begin{array}{l}239 \\
(31.5)\end{array}$ \\
\hline $\begin{array}{l}\text { Do you think that the initiatives from the government to achieve the status } \\
\text { of developed nation are working properly? }\end{array}$ & $\begin{array}{l}252 \\
(33.2)\end{array}$ & $\begin{array}{l}238 \\
(31.4)\end{array}$ & $\begin{array}{l}255 \\
(33.6)\end{array}$ \\
\hline $\begin{array}{l}\text { Is the cooperation of the people with the government to achieve developed } \\
\text { nation sufficient? }\end{array}$ & $\begin{array}{l}198 \\
(26.1)\end{array}$ & $\begin{array}{l}342 \\
(45.1)\end{array}$ & $\begin{array}{l}205 \\
(27.0)\end{array}$ \\
\hline $\begin{array}{l}\text { Do you think that the present education system in Malaysia is able to } \\
\text { prepare the nation to be developed by 2020? }\end{array}$ & $\begin{array}{l}219 \\
(28.9)\end{array}$ & $\begin{array}{l}369 \\
(48.6)\end{array}$ & $\begin{array}{l}158 \\
(20.8)\end{array}$ \\
\hline $\begin{array}{l}\text { Is the human resource skilled enough and ready to take challenges to } \\
\text { achieve the targets of a developed nation by 2020? }\end{array}$ & $\begin{array}{l}153 \\
(20.2)\end{array}$ & $\begin{array}{l}407 \\
(53.6)\end{array}$ & $\begin{array}{l}187 \\
(24.6)\end{array}$ \\
\hline $\begin{array}{l}\text { Are the monitoring agencies active enough to monitor the progress } \\
\text { pertaining to all the challenges of vision 2020? }\end{array}$ & $\begin{array}{l}135 \\
(17.8)\end{array}$ & $\begin{array}{l}313 \\
(41.2)\end{array}$ & $\begin{array}{l}297 \\
(39.1)\end{array}$ \\
\hline
\end{tabular}

In the remaining six questions, the majority of the respondents answered in the negative. In particular, the respondents do not think that:

- The initiatives taken by the government to achieve the status of a developed nation are enough.

- The initiatives taken by the government to achieve the status are working properly.

- The cooperation of the people with the government to achieve developed nation is sufficient.

- The present education system in Malaysia is able to prepare the nation to be developed by 2020 .

- The human resource is skilled enough and ready to take challenges to achieve the targets of a developed nation by 2020 . 
- The monitoring agencies are active enough to monitor the progress pertaining to all the challenges of vision 2020.

The high percentages of responses under the column 'Not sure' are noteworthy. About 39\% (highest percentage under 'Not sure' category) of the respondents are not aware about the existence of any agencies that monitor the progress of achieving the status. We also find that $53.6 \%$ (overall highest percentage) of the respondents do not think that the country's human resource is skilled enough and ready to take the challenges of V-2020.

\section{Ranking of Challenges of V-2020}

Not all challenges of V-2020 are usually regarded as equally important. The respondents were asked to rank the challenges according to their perceived importance. The most perceived important one is to be assigned rank 1, the second most the rank 2, etc. After collecting all the ranks assigned by them, arithmetic means were computed and these are shown in the second column of Table 4. As per the assignment of the ranks, the lower the mean value, the higher is the importance. Based upon this premise, the ordinal ranks of the challenges are shown. The three most important challenges are found to be:

Table 4. Ranking of challenges of V-2020

\begin{tabular}{|l|c|c|c|}
\hline Challenge & $\begin{array}{c}\text { Mean } \\
\text { Rank } \\
\text { (cardinal) }\end{array}$ & $\begin{array}{c}\text { Mean } \\
\text { Rank } \\
\text { (ordinal) }\end{array}$ & Weight* \\
\hline $\begin{array}{l}\text { Establishing a united Malaysian nation made up of one Bangsa } \\
\text { Malaysia (Malaysian nation) }\end{array}$ & 4.383 & 2 & 0.178 \\
\hline $\begin{array}{l}\text { Creating a psychologically liberated, secure and developed Malaysian } \\
\text { society }\end{array}$ & 4.896 & 3 & 0.156 \\
\hline Fostering and developing a mature democratic society & 4.912 & 4 & 0.133 \\
\hline Establishing a fully moral and ethical society & 4.037 & 1 & 0.200 \\
\hline Establishing a mature, liberal and tolerant society & 5.203 & 6 & 0.089 \\
\hline Establishing a scientific and progressive society & 5.578 & 8 & 0.044 \\
\hline $\begin{array}{l}\text { Establishing a fully caring society } \\
\text { Ensuring an economically just society, in which there is fair and } \\
\text { equitable distribution of wealth of the nation }\end{array}$ & 5.686 & 9 & 0.022 \\
\hline $\begin{array}{l}\text { Establishing a prosperous society with an economy that is fully } \\
\text { competitive, dynamic, robust and resilient }\end{array}$ & 5.346 & 7 & 0.111 \\
\hline
\end{tabular}

* Based upon ordinal mean ranks

- Establishing a fully moral and ethical society

- Establishing a united Malaysian nation made up of one Bangsa Malaysia (Malaysian nation)

- Creating a psychologically liberated secure and developed Malaysian society

It is to noted that, economic challenge (challenge number 9) is not ranked one, though someone might initially think. In fact, this has been assigned overall rank 7. Perhaps country's concern on increasing crime rate, problems related to morality (albeit in certain cases) and fragile unity among various races underlie the fact. In fact, the former Prime Minister Tun Dr. Mahathir, in one of his speeches, mentioned 
that he would be surprised if the Malaysian nation does not consider the challenge of establishing a united Malaysian nation as the most crucial one (Mohamad, 1991). This underscores the importance of the matter in the Malaysian context. It is interesting to note that the present prime minister Dato' Seri Najib Tun Razak's national slogan is "1 Malaysia" (Razak, 2009; Lim, 2009). This is reasonable and expected as unity is an antecedent for any kind of development in a multi-racial country like Malaysia.

Cardinal weights (where sum equals to unity) of the challenges are determined from their mean ordinal ranks by using the following formula:

$$
w_{i}=\frac{n-r_{i}+1}{\sum_{l}\left(n-r_{i}+1\right)}
$$

where $\mathrm{n}=$ number of challenges and $r_{i}=$ rank of the $\mathrm{i}^{\text {th }}$ challenge. The weights are shown in the last column of Table 4 .

\section{Suggestions for achieving V-2020}

The main purpose of the questionnaire survey was to collect the public suggestions to expedite the process of achieving the developed status. As it was anticipated, the respondents touched upon a wide variety of issues and initially they (the suggestions) were very unstructured. People were vocal about government responsibility, equitable distribution of wealth, preventing corruption and, of course, the ubiquitous issue of economy. Altogether 423 suggestions (some of them are mere comments) were received of which many are repeated a large number of times. For example, numerous people voiced out 'develop human capital', 'fair and equitable distribution of wealth', 'eliminate corruption', etc.

All the suggestions provided by the respondents are classified into 20 categories. Thirteen of 20 categories possess a number of distinct items. An affinity diagram has been formed for these 13 categories (Exhibit 1). However, Islam (2005) comments that mere construction of an affinity diagram is not sufficient, rather one needs to prioritize the items within the components of the diagram in order to know which items deserve more attention.

The distinct items are singled out and used for prioritization by the AHP. In fact, to frame a distinct item, few similar items have been combined. This does not only reduce the number of items but also makes it amenable to the application of AHP (Saaty, 2005). For example, under the category of 'Social Life', the suggestion 'Inculcate sharing and caring culture in the society' is actually an integrated form of the following suggestions:

- Culture of caring each other and respect others opinion.

- As a Malaysian, (I) think it does not matter if we achieve a developed nation status successfully by 2020 unless we realize that the norm values among Malaysians, namely understanding and helping each other are more important in order to maintain and remain prosperous in the country for ever.

- More caring, giving and taking.

- Malaysian should make their heart as nice as good hearted people.

- Everybody should support whatever has been done by Malaysia and think positive for every development. 
Exhibit 1 . The affinity diagram of V-2020

\section{Corruption}

$\mathrm{CO}_{1}$ : Remove corrupt leaders

$\mathrm{CO}_{2}$ : Eradicate corrupt practices

$\mathrm{CO}_{3}$ : Stop bribery at all levels of the society

$\mathrm{CO}_{4}$ : Replace 'know-who' by 'know-how' in awarding government projects

\section{Economy}

$\mathrm{EC}_{1}$ : Sustainable economic development

$\mathrm{EC}_{2}$ : Control of economy not by one nation but by Malaysian nation

$\mathrm{EC}_{3}$ : Elimination of poverty

$\mathrm{EC}_{4}$ : Zero unemployment

$\mathrm{EC}_{5}$ : High level of per capita income

\section{Education}

$\mathrm{ED}_{1}$ : Ensure that the programs offered in the public and private universities are in the line with market need.

$\mathrm{ED}_{2}$ : Equal opportunities of education for all races

$\mathrm{ED}_{3}$ : More creativity and innovation in education system

$\mathrm{ED}_{4}$ : Enhance quality of education at the primary level

$\mathrm{ED}_{5}$ : Education should not be only examination oriented

$\mathrm{ED}_{6}$ : Develop excellent universities

$\mathrm{ED}_{7}$ : Improve academic system especially in the rural areas

\section{Environment}

$\mathrm{EN}_{1}$ : Zero pollution

$\mathrm{EN}_{2}$ : Development without destroying the environment

\section{Freedom of Expression}

$\mathrm{FE}_{1}$ : Press freedom

$\mathrm{FE}_{2}$ : Public freedom of expression

\section{Government Responsibility}

$\mathrm{GO}_{1}$ : Strong government with integrity and good governance

$\mathrm{GO}_{2}$ : Transparent government

$\mathrm{GO}_{3}$ : Close cooperation between private and public sectors

$\mathrm{GO}_{4}$ : Avoid bureaucracy

$\mathrm{GO}_{5}$ : Appoint a monitoring agency to oversee meeting challenges of Vision 2020

$\mathrm{GO}_{6}$ : Elect morally upright leaders in the government

$\mathrm{GO}_{7}$ : Change the mindset of politicians

$\mathrm{GO}_{8}$ : Full democracy

\section{Human Capital Development}

$\mathrm{HC}_{1}$ : Develop more skilled workforce

$\mathrm{HC}_{2}$ : Develop right attitude among citizens

$\mathrm{HC}_{3}$ : Develop a morally upright society

$\mathrm{HC}_{A}$ : Malavsians should seek more knowledge and education 


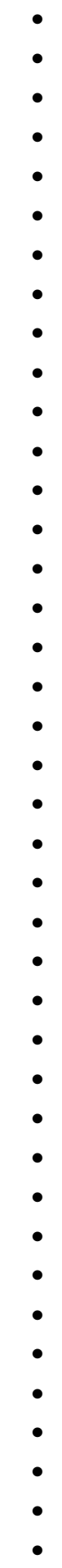

The AHP prioritization process is applied in each category of the affinity diagram. The prioritization matrices are shown in Exhibit 2. The priorities of the items under each category are shown in Table 5.

Exhibit 2. A sample of completed AHP pairwise comparison matrices 


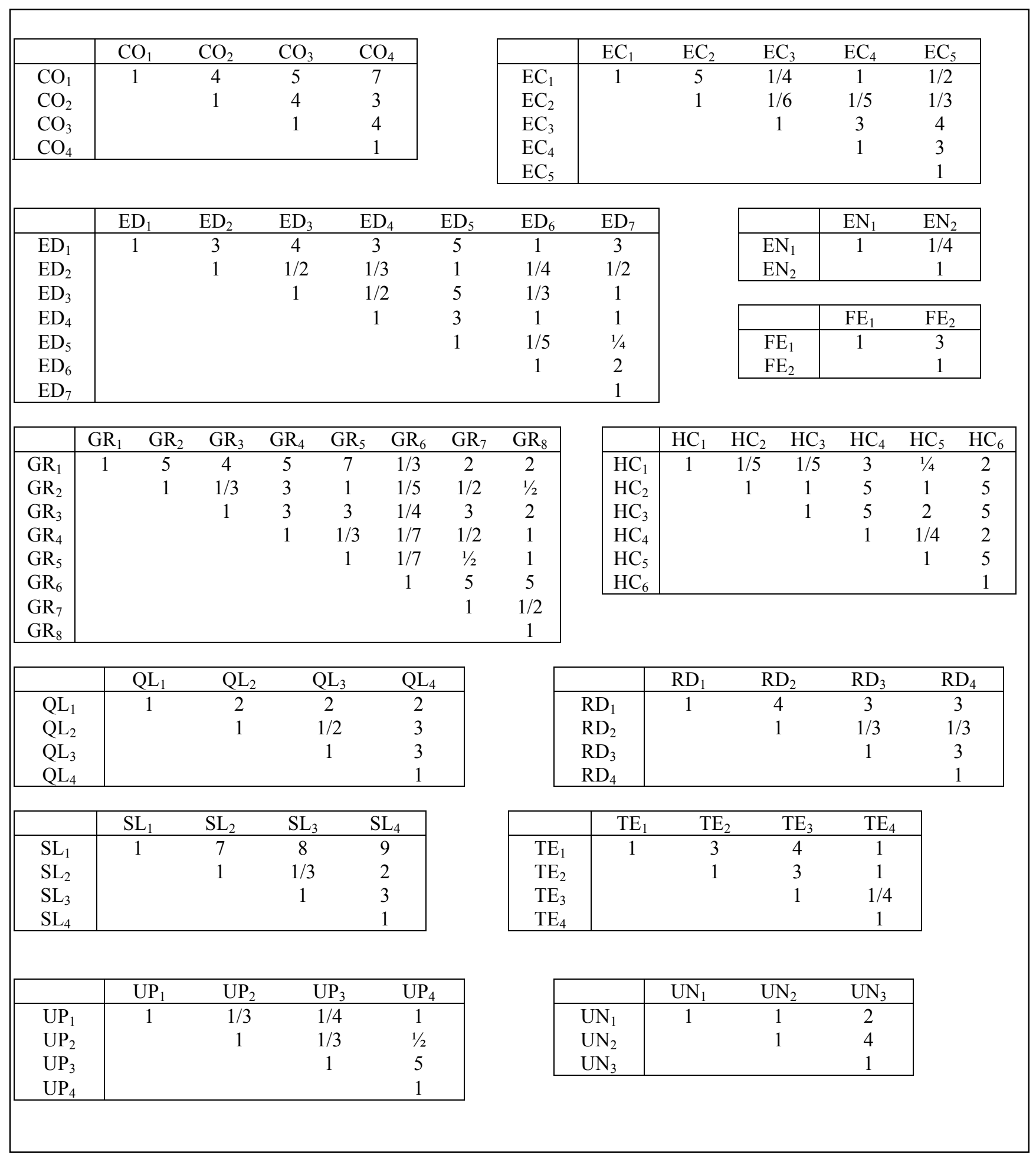

Table 5. Priorities of the items in each category of the affinity diagram

\begin{tabular}{|l|l|l|l|l|l|l|l|}
\hline Category & Items & Priorities & $\begin{array}{l}\text { Consistency } \\
\text { Ratio }\end{array}$ & Category & Items & Priorities & $\begin{array}{l}\text { Consistency } \\
\text { Ratio }\end{array}$ \\
\hline Corruption & $\mathrm{CO}_{1}$ & 0.583 & 0.14 & Economy & $\mathrm{EC}_{1}$ & 0.142 & 0.08 \\
\hline
\end{tabular}




\begin{tabular}{|c|c|c|c|c|c|c|c|}
\hline & $\begin{array}{l}\mathrm{CO}_{2} \\
\mathrm{CO}_{3} \\
\mathrm{CO}_{4}\end{array}$ & $\begin{array}{l}0.238 \\
0.121 \\
0.057\end{array}$ & & & $\begin{array}{l}\mathrm{EC}_{2} \\
\mathrm{EC}_{3} \\
\mathrm{EC}_{4} \\
\mathrm{EC}_{5}\end{array}$ & $\begin{array}{l}0.044 \\
0.463 \\
0.213 \\
0.138\end{array}$ & \\
\hline Education & $\begin{array}{l}\mathrm{ED}_{1} \\
\mathrm{ED}_{2} \\
\mathrm{ED}_{3} \\
\mathrm{ED}_{4} \\
\mathrm{ED}_{5} \\
\mathrm{ED}_{6} \\
\mathrm{ED}_{7}\end{array}$ & $\begin{array}{l}0.294 \\
0.057 \\
0.106 \\
0.152 \\
0.042 \\
0.229 \\
0.120\end{array}$ & 0.04 & $\begin{array}{l}\text { Government } \\
\text { Responsibility }\end{array}$ & $\begin{array}{l}\mathrm{GR} \\
\mathrm{GR} \\
\mathrm{GR}_{3} \\
\mathrm{GR}_{4} \\
\mathrm{GR}_{5} \\
\mathrm{GR}_{6} \\
\mathrm{GR} \\
\mathrm{GR}_{8}\end{array}$ & $\begin{array}{l}0.224 \\
0.052 \\
0.123 \\
0.037 \\
0.052 \\
0.364 \\
0.072 \\
0.076\end{array}$ & 0.07 \\
\hline Environment & $\begin{array}{l}\text { EN1 } \\
\text { EN2 }\end{array}$ & $\begin{array}{l}0.200 \\
0.800\end{array}$ & 0.00 & $\begin{array}{l}\text { Freedom of } \\
\text { Expression }\end{array}$ & $\begin{array}{l}\mathrm{FE}_{1} \\
\mathrm{FE}_{2}\end{array}$ & $\begin{array}{l}0.750 \\
0.250\end{array}$ & 0.00 \\
\hline $\begin{array}{l}\text { Human } \\
\text { Capital } \\
\text { Development }\end{array}$ & $\begin{array}{l}\mathrm{HC}_{1} \\
\mathrm{HC}_{2} \\
\mathrm{HC}_{3} \\
\mathrm{HC}_{4} \\
\mathrm{HC}_{5} \\
\mathrm{HC}_{6}\end{array}$ & $\begin{array}{l}0.082 \\
0.276 \\
0.313 \\
0.055 \\
0.229 \\
0.044\end{array}$ & 0.04 & $\begin{array}{l}\text { Quality of } \\
\text { Life }\end{array}$ & $\begin{array}{l}\mathrm{QL}_{1} \\
\mathrm{QL}_{2} \\
\mathrm{QL}_{3} \\
\mathrm{QL}_{4}\end{array}$ & $\begin{array}{l}0.383 \\
0.210 \\
0.295 \\
0.112\end{array}$ & 0.08 \\
\hline R\&D & $\begin{array}{l}\mathrm{RD}_{1} \\
\mathrm{RD}_{2} \\
\mathrm{RD}_{3} \\
\mathrm{RD}_{4}\end{array}$ & $\begin{array}{l}0.494 \\
0.082 \\
0.270 \\
0.154\end{array}$ & 0.09 & Social Life & $\begin{array}{l}\mathrm{SL}_{1} \\
\mathrm{SL}_{2} \\
\mathrm{SL}_{3} \\
\mathrm{SL}_{4}\end{array}$ & $\begin{array}{l}0.713 \\
0.059 \\
0.152 \\
0.076\end{array}$ & 0.09 \\
\hline Technology & $\begin{array}{l}\mathrm{TE}_{1} \\
\mathrm{TE}_{2} \\
\mathrm{TE}_{3} \\
\mathrm{TE}_{4}\end{array}$ & $\begin{array}{l}0.405 \\
0.216 \\
0.079 \\
0.300\end{array}$ & 0.05 & $\begin{array}{l}\text { Unbiased } \\
\text { Practice }\end{array}$ & $\begin{array}{l}\mathrm{UP}_{1} \\
\mathrm{UP}_{2} \\
\mathrm{UP}_{3} \\
\mathrm{UP}_{4}\end{array}$ & $\begin{array}{l}0.109 \\
0.177 \\
0.543 \\
0.171\end{array}$ & 0.13 \\
\hline Unity & $\begin{array}{l}\text { UN1 } \\
\text { UN2 } \\
\text { UN3 } \\
\end{array}$ & $\begin{array}{l}0.376 \\
0.474 \\
0.149 \\
\end{array}$ & 0.05 & & & & \\
\hline
\end{tabular}

From the prioritization exercise, we identify the most important suggestions (selected only the first and second rank holders) under each category and these are shown below:

- Remove corrupt leaders $\left(\mathrm{CO}_{1}\right)$

- Eradicate corrupt practices $\left(\mathrm{CO}_{2}\right)$

- Eliminate poverty $\left(\mathrm{EC}_{3}\right)$

- Zero unemployment $\left(\mathrm{EC}_{4}\right)$

- Ensure that the programs offered in the public and private universities are in the line with market need $\left(\mathrm{ED}_{1}\right)$

- Develop excellent universities $\left(\mathrm{ED}_{6}\right)$

- Develop without destroying the environment $\left(\mathrm{EN}_{2}\right)$

- Press freedom $\left(\mathrm{FE}_{1}\right)$ 
- Elect morally upright leaders in the government $\left(\mathrm{GR}_{6}\right)$

- Strong government with integrity and good governance $\left(\mathrm{GR}_{1}\right)$

- Develop morally upright society $\left(\mathrm{HC}_{3}\right)$

- Develop right attitude among citizens $\left(\mathrm{HC}_{2}\right)$

- Develop rural areas $\left(\mathrm{QL}_{1}\right)$

- Improve public health-care facilities $\left(\mathrm{QL}_{3}\right)$

- $\mathrm{R} \& \mathrm{D}$ in critical sectors in agriculture and industry $\left(\mathrm{RD}_{1}\right)$

- Recognize and encourage research in universities $\left(\mathrm{RD}_{3}\right)$

- Crime prevention $\left(\mathrm{SL}_{1}\right)$

- Develop knowledge-based society $\left(\mathrm{TE}_{1}\right)$

- Achieve technology mastery $\left(\mathrm{TE}_{4}\right)$

- Ensure that all ethnic groups are equally treated $\left(\mathrm{UP}_{3}\right)$

- Enhance national unity by eliminating discrimination $\left(\mathrm{UN}_{2}\right)$

Expounding the details of all of the above suggestions is beyond the scope of this paper. Nevertheless, brief accounts of some of these are provided below.

Elimination of Corruption: Through empirical investigation, Strauss (2001) finds that corruption affects growth and government efficiency in developing countries. Mauro (1995) also found corruption as a robust negative determinant of investment, which in turn has negative implication for the rate of growth in the economy.

Since 1995, Transparency International has been publishing an annual Corruption Perception Index (CPI) that ranks the countries of the world according to the degree to which corruption is perceived to exist among public officials and politicians. The organization defines corruption as "the abuse of entrusted power for private gain". However, what is legally defined to be corruption differs between jurisdictions: a political donation legal in some jurisdiction may be illegal in another; a matter viewed as acceptable tipping in one country may be construed as bribery in another. The 2008 Transparency International poll covered over 180 countries. A higher CPI means less (perceived) corruption. According to the CPI, Malaysia's rank in 2008 is $47^{\text {th }}$ in the world. This shows Malaysia has ample rooms for improving public perception about corruption. In fact, people have been highly vocal against any kind of corruption in the government machinery.

Eradication of Poverty: Poverty eradication must be the first step in the larger effort to address disparities in the socio-economic achievements of the country. Malaysia's present poverty eradication strategies include, among others, increasing public healthcare to spur productivity and reduce absenteeism, providing housing, cooperation with non-governmental organizations to improve the environment and living conditions. Under the present Ninth Malaysian Plan, the government is enhancing Amanah Ikhtiar Malaysia and various capacity building programs to ensure their effectiveness in lifting households out of poverty. The government also wants to reduce rural-urban income ratio from 1:2.11 in 2004 to $1: 2.0$ by 2010 .

According to Mahathir, no one is against the eradication of absolute poverty regardless of race, and irrespective of geographical location. All Malaysians, whether they live in the rural or the urban areas, whether they are in the south, north, east or west, must be moved above the line of absolute poverty.

Developing Human Capital: It is the human resource that is the most vital for achieving V-2020. A country may be developed materialistically, but if its human resources are kept at the bay, then it is unlikely to sustain the economic development. The same thing was communicated to us by numerous people when we embarked upon the task of data collection. Human capital has bearing on many aspects including public delivery or civil service. In fact, civil servants have emphatic role in achieving V-2020. 
To bring smoothness in public administration, bureaucracy and bottlenecks must be removed. One respondent maintained: public delivery system needs to be improved in order to realize V-2020. V-2020 requires complete public readiness to embrace the necessary changes and to do so it is imperative for a quantum leap towards human resource development. Citing Japan, Switzerland and South Korea, Abdullah (1993) says these countries do not have minerals and the climate, land structure and soil are not conducive to agriculture. Yet these countries have achieved spectacular economic growth on the strength and ingenuity of their human resources.

National Unity: According to the former PM, Tun Dr. Mahathir Mohamad (Mohamad, 1991), the most important among all challenges is ensuring a united Malaysian nation:

But it would be surprising if the first strategic challenge which I have mentioned the establishment of a united Malaysian nation is not likely to be the most fundamental, the most basic.

The present Malaysian Premier, Dato' Seri Najib Tun Razak, said ( see Sennyah and Sharmini (2005), p. 2):

Racial and religious differences, skin color and cultures should not be obstacles to unity, as, in principle, all races had the same aims and desires in life.

For the remaining categories (other than those included in the affinity diagram) though apparently there are many suggestions, but basically they augur the same issue. Therefore, these suggestions are not itemized as the categories put in the affinity diagram; in other words, we have only one item under this type of category. This item has been expressed by different respondents in different ways. In the following we discuss this type of one item categories.

Balanced Development: A country which is developed in only one dimension, e.g, economy, may not be called a developed nation as encapsulated in the statement of V-2020. The country needs to be developed multilaterally. This has been echoed by the following messages from the respondents. As it is seen, the messages are essentially the same, only words used are different.

- In my opinion, development that we, Malaysian should have must be balanced in all aspects of life, morally, intellectually, economically, spiritually, socially and politically ${ }^{3}$.

- A more comprehensive meaning of developed nation rather than focusing on material/physical development but intellectual, moral and spiritual as well.

- The parameter and definition of development need to be ascertained. Development is a holistic concept. Infrastructural development alone at the expense of moral, ethical, and social developments may not be a development in the true sense of the term. As such competing to stay at development stage must not ignore the social engineering of the society on moral and spiritual bases. Otherwise development for the sake of development without adequate moral and spiritual bases to cushion the shocks of physical development may merely lead to devil-upment (and not development)!

- Not focused on one area only - must be balanced in all areas.

3 While articulating the suggestions, all the respondents have not followed the grammatical rules strictly. We have presented the suggestions as articulated by the respondents. 
Public Responsibility: The responsibility of realizing V-2020 is not solely shouldered to the government or few individuals; rather every citizen of the nation has a stake towards this achievement. This has been articulated by the respondents in a manifold ways:

- Everybody has to play a role in achieving the developed nation status.

- Malaysians must support all the initiatives taken by the government and new policies promulgated by it.

- Every citizen should change his or her attitude and mentality to achieve V-2020.

- If Malaysia does not achieve the status of develop nation by the year 2020, everybody should triple up efforts to achieve the targets.

Communication: As mentioned before, achievement of the national vision cannot be the responsibility of a certain number of individuals; in fact, it is the responsibility of all the people. Therefore, a nationwide awareness about V-2020 is a must. This matter has been articulated by the people in the following ways:

- Create awareness in the Malaysian society about how important this V-2020 is.

- To educate the Malaysians more about the V-2020 nine challenges.

- I think government should update the public regarding the status of achievement of V-2020.

- To educate the Malaysians more about the V-2020 nine challenges.

Ethics: Regarding ethics, overall people's voice is that if the citizens do not behave ethically or morally, then mere materialistic development has no meaning. Ethical dimension of the society has been encapsulated by the following suggestions:

- Ethical dimension should be progressively addressed, tackled and solved. Unless this aspect of morality is not solved, achievement in other aspects is virtually not possible.

- We should establish a fully moral and ethical society before we achieve a developed nation.

- First and foremost, Malaysians should be aware that in order to develop a nation, they must develop themselves with strong moral and ethical values.

- Society has to change its way of thinking, more open minded, work honest and fair.

Family Institution: Many people have re-emphasized the proverb "Charity begins at home". Children must be guided right from the beginning about the ethics and morality and parents have a great role in this regard. Right attitude and integrity in the early stage pave the way for becoming a good citizen in future. This matter has been expressed by the following suggestions:

- To strengthen the family leadership.

- Honor family institution. Do not put parents in the condition where they have to work until they leave their children at the hand of foreigners (foreign maids). If family intuition is honored country will also follow suit.

- Try to develop and nurture the children from the beginning with high ethical and moral values.

- Teaching moral values to the kids right from early stage.

Benchmarking: Benchmarking is a management practice used for achieving radical change in some particular area. In the business context, organizations benchmark others to improve their business processes. There are numerous examples of successful benchmarking exercises (Andersen et al., 2008; Fawcett et al., 2009). In the national level too, similar exercises can be conducted. For example, Malaysia can learn from Japan regarding how the country maintains its environment and ecosystem while being engaged in developmental activities. What are the strategies of Japan in $R \& D$, transportation, public 
health, education, etc? Malaysia can learn from all these. A number of respondents have supported this idea:

- To follow Japan and Korea, how they became developed nations.

- Collaboration with developed country.

Spiritual Development: In general, Malaysians are religious minded and they like to see the spiritual development has taken place in the minds of all Malaysians in tandem with the socio-economic development in the country. A large number of Malaysians' views is that materialistic development has no meaning if there is no mental peace among them! The following suggestions are examples of some of their aspiration of dealing with a developed religious life:

- No matter how developed our country is, the development of spiritual and mental is very important.

- Strengthen the spiritual side first.

- Material development must be complemented with social and spiritual development. More emphasis should be placed to social development and also spiritual development.

\section{Conclusions}

Achieving the status of a developed country is a common vision to many developing nations. Countries like India, Malaysia have even set up a specific timeline (which is 2020 AD) to reach at the milestone. The present research is carried out to gauge the progress made to achieve Malaysian V-2020. In general, people of the nation feel that many more things need to be done before Malaysia can declare herself a developed nation. It is not only in economical aspect, but also the country needs to pay serious attention to human resource development - especially prevention of crime and corruption from all levels of the greater society. The survey respondents suggested that the government should play a dual role - in one hand, the government should play its traditional role in strengthening economy, ensuring quality education to its people and maintain law and order, on the other hand, it should make the people ready to face the challenges ahead and take the necessary steps to address them successfully.

\section{REFERENCES}

Abdullah, O.Y. (1993). Human resource development: The key towards a developed and industrialized society. In: Hamid, ASA, editor. Malaysia's Vision 2020: Understanding the Concept, Implications and Challenges (p. 315-326), Kuala Lumpur: Pelanduk Publications.

Andersen, B., Henriksen, B., \& Spjelkavik, I. (2008). Benchmarking applications in public sector principal-agent relationships. Benchmarking: An International Journal, 15(6), 723-741.

Fawcett, S.E., Wallin, C., Allred, C., Magnan, G. (2009). Supply chain information sharing: Benchmarking a proven path. Benchmarking: An International Journal, 16(2), 222-246.

Islam, R. (2005). Prioritization of ideas in an affinity diagram by AHP: an example of K-economy. IIUM Journal of Economics and Management, 13(1), 71-108.

Kassim, M.S.M. (1993). Vision 2020: Its linkages with the sixth Malaysian plan and the second outline perspective plan. In: Hamid ASA, editor. Malaysia's Vision 2020: Understanding the Concept, Implications and Challenges (p. 67-87), Kuala Lumpur: Pelanduk Publications. 
Lim, T. (2009). One Malaysia. New Straits Times, May 31, p. R8.

Mauro, P. (1995). Corruption and growth. Quarterly Journal of Economics, CX(442), 681-712.

Mohamad, M. (1991). The way forward: Vision 2020. www.epu.jpm.my, accessed on April 28, 2008.

Rahman, O.A. (1993). Industrial targets of vision 2020: The science and technology perspective. In: Hamid ASA, editor. Malaysia's Vision 2020: Understanding the Concept, Implications and Challenges (p. 271-299), Kuala Lumpur: Pelanduk Publications.

Razak, N.T. (2009). 1 Malaysia. www.1malaysia.com.my, accessed on April 15, 2009.

Saaty, T.L. (2005). Theory and Applications of the Analytic Network Process: Decision Making with Benefits, Opportunities, Costs, and Risks. Pittsburgh: RWS Publications.

Sennyah, P. \& Sharmini, P. (2005). Go for lifelong education. New Straits Times, May 17, p. 2.

Staff Reporter (2005). Selangor developed state: Did you know? New Straits Times, August 27, p. 30.

Strauss, T. (2001). Growth and government: Is there a difference between developed and developing countries? Economics of Governance, 2, 135-157.

\footnotetext{
${ }^{\mathrm{i}}$ The term developed country is used to categorize countries with developed economies in which the tertiary and quaternary sectors of industry dominate. This level of economic development usually translates into a high per capita income and a high Human Development Index. World Bank defines high income countries as countries with per capita GNP of $\$ 10,000$ or more. Traditionally, Canada and the United States in North America, Japan in Asia, Australia and New Zealand in Oceania, and most countries in Northern Europe and Western Europe have been considered as developed countries. Despite their high per capita GNP, the GCC countries in the Middle East are generally not considered developed countries because their economies depend overwhelmingly on oil production and export.
}

Generally speaking, a nation is said to be developed if it has well-developed political, economic, physical, educational and infrastructural institutions in place and every citizen, irrespective of his/her class, sex, or birth enjoys the confidence to live his/her life by choice and not by imposition from any sector, provided such liberty is within the accepted moral norms of the society, without fear or inhibition of any kind or from any quarter. Developed countries have low level of illiteracy, poverty, infrastructural deficiencies, social imbalances, bureaucratic and political bottlenecks, etc and work in cohesion and unison in one voice and dictum and achieves as a result, the highest in the fields of science, and discoveries, at any given point of time and leads the field with highly developed systems in the area of law, justice and social retribution.

ii Speech delivered by Tun Abdul Ghafar Baba at the opening ceremony of National Seminar Towards a Developed and Industrialized Society: Understanding of the Concepts, Implications and Challenges of Vision 2020, Kuala Lumpur, 5-7 December, 1991. 